*akls View/Frint Document Cover Sheet tow

This document was retrieved from the Boeing ISEARCH System.

Accession \#: D196055034

Document \#: SD-WM-ER-513

Title/Desc:

TANK 241U204 HEADSPACE GAS \& VAPOR CHARACTERIZATION RESULTS FOR SAMPLES COLLECTED IN $8 / 1995$ 


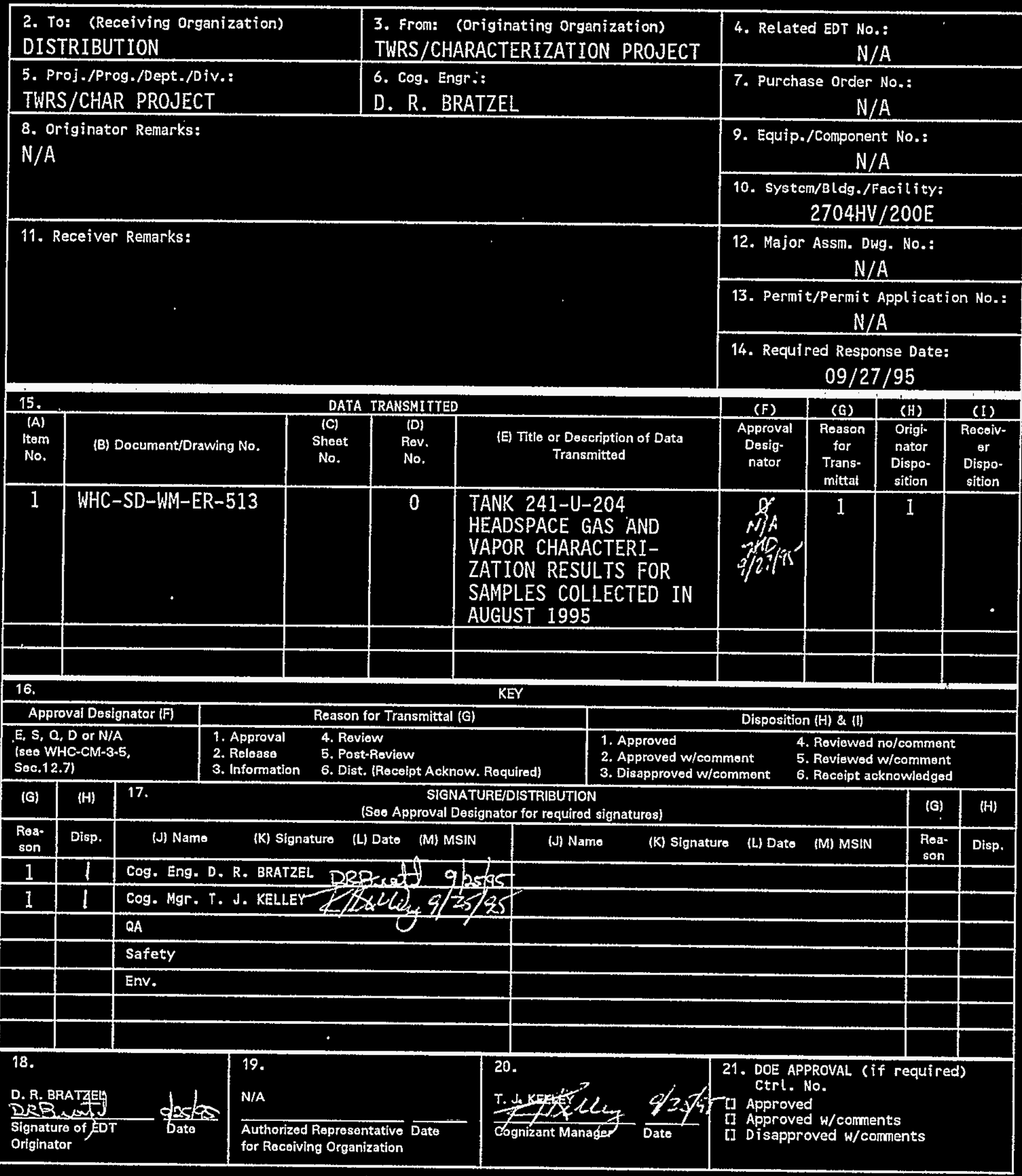




\section{RELEASE AUTHORIZATION}

Document Number: WHC-SD-WM-ER-513, REV 0

$\begin{array}{ll}\text { Dank 241-U-204 Headspace Gas and Vapor } \\ \text { Document Title: } & \text { Characterization Results for Samples Collected in }\end{array}$
August 1995

Release Date: $\quad 9 / 28 / 95$

This document was reviewed following the procedures described in WHC-CM-3-4 and is:

APPROVED FOR PUBLIC RELEASE

WHC Information Release Administration Specialist:
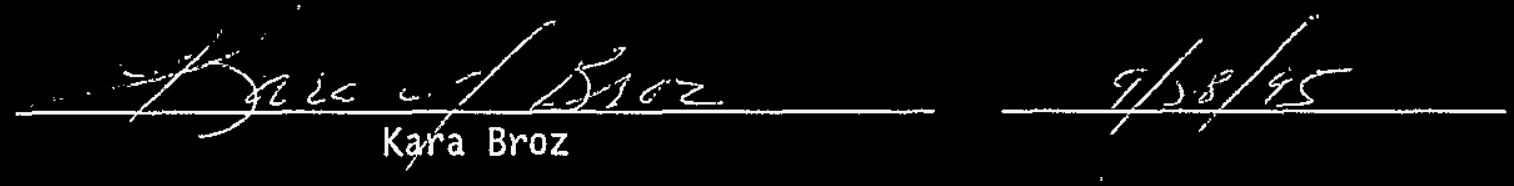

TRADEMARK DISCLAIMER. Reference herein to any specific commercial product, process, or service by trade name, trademark, manufacturer, or otherwise, does not necessarily constitute or imply its endorsement, recommendation, or favoring by the United States Government or any agency thereof or its contractors or subcontractors.

This report has been reproduced from the best available copy. Available in paper copy. Printed in the United States of America. To obtain copies of this report, contact:

Westinghouse Hanford Company - Document Control Services

P.0. Box 1970, Mailstop H6-08, Richland, WA 99352

Telephone: (509) 372-2420; Fax: (509) 376-4989 


\section{Title}

TANK 241-U-204 HEADSPACE GAS AND VAPOR CHARACTERIZATION RESULTS FOR SAMPLES COLLECTED IN AUGUST 1995

5. Key Words

CHARACTERIZATION OBJECTIVES, TANK HEADSPACE, SAMPLING EVENT, INORGANIC GASES, ORGANIC VAPORS
3. Number

HHC-SD-NW-ER-513
4. Rev No.

0

\section{Author}

Name: D. R. BRATZEL

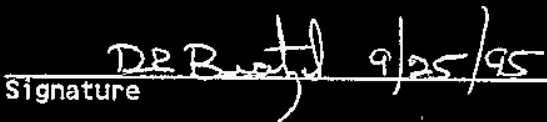

Organization/Charge code $75640 / N 4 A B 1$

7. Abstract

Significant changes have been made to all of the original vapor characterization reports. This report documents specific headspace gas and vapor characterization results for all vapor sampling events to date. In addition, changes have been made to the original vapor reports to qualify the data based on quality assurance issues associated with the performing laboratories. 
WHC-SD-WM-ER-513

Revision 0

UC-2070

\title{
Tank 241-U-204 Headspace Gas and Vapor Characterization Results for Samples Collected in August 1995
}

\author{
J. L. Huckaby \\ Pacific Northwest Laboratories \\ D. R. Bratzel \\ Westinghouse Hanford Company
}

Date Published

September 1995

Prepared for the U.S. Department of Energy

Office of Environmental Restoration and

Waste Management

QR Westinghouse P.O Box 1970

Hanford Company Richland, Washington

Management and Operations Contractor for the

U.S. Department of Energy under Contract DE-ACO6-87RL 10930 
WHC-SD-WM-ER-513 Rev. 0

Tank 241-U-204 Headspace Gas and Vapor Characterization Results

for Samples Collected in August 1995

September 26, 1995

J. L. Huckaby

Multimedia Exposure Assessment

Pacific Northwest Laboratories

D. R. Bratzel

Waste Tank Characterization Program

Westinghouse Hanford Company 
WHC-SD-WM-ER-513 Rev. 0

\section{Contents}

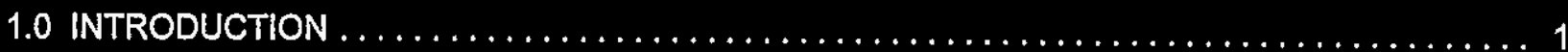

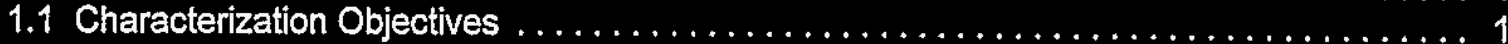

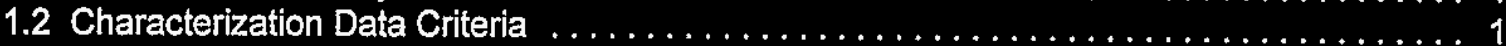

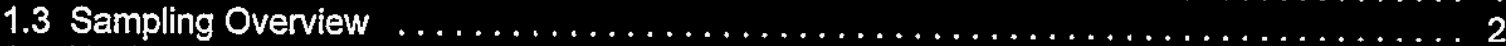

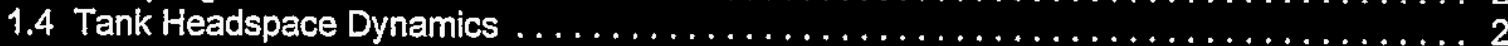

2.0 SAMPLING EVENT $\ldots \ldots \ldots \ldots \ldots \ldots \ldots \ldots \ldots \ldots \ldots \ldots \ldots \ldots \ldots \ldots \ldots \ldots$

3.0 INORGANIC GASES AND VAPORS $\ldots \ldots \ldots \ldots \ldots \ldots \ldots \ldots \ldots \ldots \ldots \ldots \ldots \ldots \ldots$

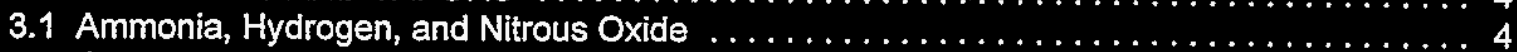

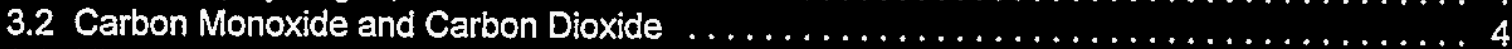

3.3 Nitric Oxide, Nitrogen Dioxide, Water and Tritium $\ldots \ldots \ldots \ldots \ldots \ldots \ldots \ldots \ldots \ldots$

3.4 Discussion of Inorganic Gases and Vapors $\ldots \ldots \ldots \ldots \ldots \ldots \ldots \ldots \ldots \ldots$

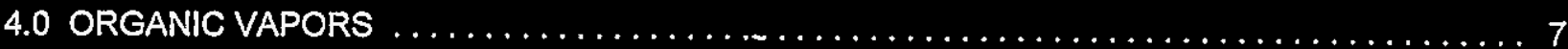

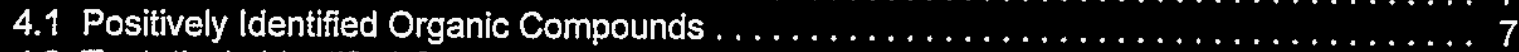

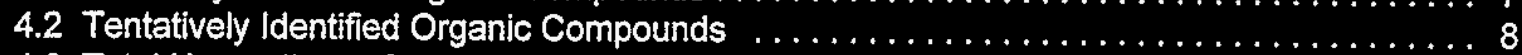

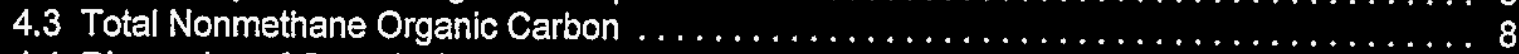

4.4 Discussion of Organic Compounds $\ldots \ldots \ldots \ldots \ldots \ldots \ldots \ldots \ldots \ldots \ldots \ldots$

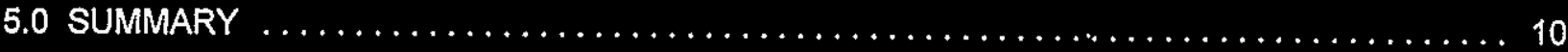

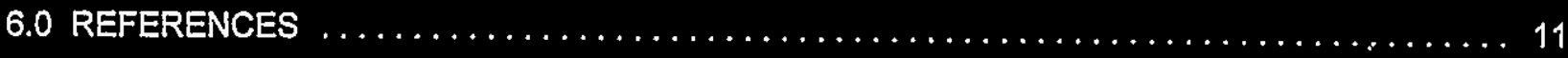

\section{Acronyms and Abbreviations}

$\begin{array}{ll}\text { CES } & \text { consensus exposure standard } \\ \text { EPA } & \text { Environmental Protection Agency } \\ \text { GC } & \text { gas chromatograph } \\ \text { GC/MS } & \text { gas chromatograph/mass spectrometer } \\ \text { LFL } & \text { lower flammability limit } \\ \text { MS } & \text { mass spectrometer } \\ \text { NFPA } & \text { National Fire Protection Association } \\ \text { NPH } & \text { normal paraffinic hydrocarbon } \\ \text { PNL } & \text { Pacific Northwest Laboratory } \\ \text { ppmv } & \text { parts per million by volume, } 1 \text { ppmv }=10^{-4} \text { vol\% } \\ \text { TNMOC } & \text { total nonmethane organic carbon } \\ \text { TO-12 } & \text { task order 12 } \\ \text { TO-14 } & \text { task order } 14 \\ \text { TST } & \text { triple sorbent trap } \\ \text { vol\% } & \text { percent by volume, 1 vol\% }=10,000 \text { ppmv } \\ \text { VSS } & \text { vapor sampling system } \\ \text { WHC } & \text { Westinghouse Hanford Company }\end{array}$




\section{WHC-SD-WM-ER-513 ReV. 0}

\section{Acknowledgements}

The authors wish to thank Chris Simonen for her work verifying data and generating tables, and Shas Mattigod for his help with the construction and reviews of this document. The authors also wish to thank Luther Buckiey, Clarence Homi, and Tom Kunthara for their contributions to the final reviews and publication of this document. 
WHC-SD-WM-ER-513 Rev. 0

Tank 241-U-204 Headspace Gas and Vapor Characterization Results

for Samples Collected in August 1995

\subsection{INTRODUCTION}

\subsection{Characterization Objectives}

Tank U-204 headspace ges and vapor samples were collected and analyzed to help determine the potential risks of fugitive emissions to tank farm workers. The drivers and objectives of waste tank headspace sampling and analysis are discussed in Program Plan for the Resolution of Tank Vapor /ssues (Osborne and Huckaby 1994). Tank U-204 was vapor sampled in accordance with Data Quality Objectives for Generic In-Tank Health and Safety Issue Resolution (Osborne et al. 1995). Results presented here represent the best available data on the headspace constituents of tank U-204.

\subsection{Characterization Data Criteria}

Data Quality Objectives for Generic In-Tank Health and Safety Issue Resolution describes parameters for data collection to ensure appropriate conclusions can be drawn from the data. Tank headspace characterization data were collected to help in the evaluation of 1) headspace flammability, and 2) identification and quantification of compounds of toxicological concern.

Single Shell Tank Interim Operational Safety Requirements (Dougherty 1995) specifies that combustible constituents in tank headspaces be maintained below $25 \%$ of the lower flammability limit (LFL). This essentially agrees with National Fire Protection Association requirements that combustible concentrations be maintained at or below $25 \%$ of the LFL (NFPA 1992). However, current governing operating specifications for single shell Watchlist waste tanks, such as tank U-204, specify that combustible constituents be maintained at or below $20 \%$ of the LFL (WHC 1995a).

Headspace characterization data are used by Westinghouse Hanford Company (WHC) Tank Waste Remediation Systems Industrial Hygiene as source term data in the industrial hygiene strategy to protect workers from tank fugitive emissions. Because selection of worker protective equipment must be based on industrial hygiene monitoring of the work place and not on source term data (29 CFR 1910.120), tank headspace characterization data can not be used for this purpose. Furthermore, because there are mechanisms by which headspace constituents can be either diluted or concentrated as they are released to the atmosphere, the headspace characterization data should not be cọnsidered to be representative of . emissions at the point of emission.

These statements notwithstanding, the data quality objectives document specities that the industrial hygiene group be advised if constituents with toxicological properties exceed $50 \%$ of the appropriate consensus exposure standard (CES) for non-carcinogens, or $10 \%$ of the appropriate CES for carcinogens. A CES is defined as the most stringent of known regulatory or recommended toxicological values for the workplace (Osborne et al. 1995). 


\section{WHC-SD-WM-ER-513 Rev. 0}

\subsection{Sampling Overview}

Tank U-204 headspace characterization data presented here are from a single sampling event. Samples collected are thought to have been representative of the tank headspace when the tank was sampled (Meacham et al. 1995), and sample analyses were designed to provide a reasonably accurate and complete characterization of the significant headspace constituents. No assessment has been made of how the tank U-204 headspace composition changes with time, though studies of tank $\mathrm{C}-103$ suggest that composition changes probably occur very slowly in passively ventilated tanks, such as tank U-204 (Huckaby and Story 1994).

\subsection{Tank Headspace Dynamics}

Tank U-204 is passively ventilated, which means that it is allowed to exhale air, waste gases, and vapors as the barometric pressure falls, and inhale ambient air as the barometric pressure rises. Tank U-204 has its own filtered breather riser. Barometric pressure typically rises and falls on a diumal cycle, producing an average daily exchange of air equal to about $0.46 \%$ of the tank headspace (Huckaby 1994). Changes in the concentrations of tank U-204 headspace constituents due to barometric pressure changes are consequently very slow. 
WHC-SD-WM-ER-513 Rev. 0

\subsection{SAMPLING EVENT}

Headspace gas and vapor samples were collected from tank U-204 using the vapor sampling system (VSS) on August 8, 1995 by WHC Sampling and Mobile Laboratories (WHC 1995b). Sample collection and analysis were performed as directed by Tank 241-U-204 Tank Characterization Plan (Homi 1995a). The tank headspace temperature was determined to be $17.8^{\circ} \mathrm{C}$. Air from the U-204 headspace was withdrawn from a single elevation via a $6.1-\mathrm{m}$ long heated sampling probe mounted in riser 2 , and transferred via heated tubing to the VSS sampling manifold. All heated zones of the VSS were maintained at approximately $60^{\circ} \mathrm{C}$. All tank air samples were collected between 9:28 a.m. and 10:21 a.m., with no anomalies noted.

Sampling media were prepared and analyzed by WHC and Pacific Northwest Laboratories (PNL). The 36 tank air samples and 2 ambient air control samples collected are listed in Table 2-1 by analytical laboratory. Table 2-1 also lists the 14 field bianks and 2 trip blanks provided by PNL.

A general description of vapor sampling and sample analysis methods is given by Huckaby et al. (1995). The sampling equipment, sample collection sequence, sorbent trap sample air flow rates and flow times, chain of custody information, and a discussion of the sampling event itself are given in WHC (1995b). 
WHC-SD-WM-ER-513 Rev. 0

\subsection{INORGANIC GASES AND VAPORS}

Analytical results of sorbent trap and SUMMA ${ }^{T M, 1}$ canister tank air samples for selected inorganic gases and vapors are given in Table 3-1 in parts per million by volume (ppmv) in dry air. The concentration of water vapor reported in Table 3-1 has been adjusted to tank conditions as given in Section 3.3. Inorganic analyte sorbent traps and SUMMATM canisters were prepared and analyzed by PNL at PNL quality assurance impact level 2 (Clauss et al. 1995).

Analyses of inorganic analytes in sorbent traps and SUMMA ${ }^{\mathrm{TM}}$ canisters were performed within 15 and 7 days, respectively, after sample collection. This was within the allowed 60-day holding time of the WHC quality assurance project plan (Keller 1994). It should be noted that the 60-day holding time was administratively chosen, and that analytical holding times have not been established by an appropriate study of analyte stabilities in the sampling devices and in the chemical matrix of the tank air samples.

\subsection{Ammonia, Hydrogen, and Nitrous Oxide}

The reported ammonia concentration, $0.1 \mathrm{ppmv}$, is the lowest measured in any of the passively ventilated waste tanks that have been sampled. The very high relative standard deviation reported for this measurement in Table 3-1 can be attributed to the fact that the measured concentrations were very near the method detection limits. Ammonia has been observed in virtually all of the passively ventilated waste tanks that have been sampled, at concentrations as high as 1040 ppmv in BY-108 (McVeety et al. 1995). Given the LFL of ammonia in air is about 15 by volume (vol\%), the measured $0.1 \mathrm{ppmv}$ corresponds to about $0.000,07 \%$ of the LFL, and does not contribute appreciably to the flammability of the headspace.

The concentration of hydrogen in tank U-204 was determined to be $<25$ ppmv. Hydrogen in the waste tanks is of concern as a fuel. Given that the LFL for hydrogen in air is about 4 vol\%, the $<25$ ppmv of hydrogen corresponds to $<0.06 \%$ of its LFL. At this level, hydrogen is not a flammability concern in tank U-204.

The nitrous oxide concentration in tank U-204 was aiso determined to be $<25$ ppmv. Nitrous oxide has been detected in other passively ventilated waste tanks at average concentrations as low as about 12 ppmv in tank TX-105 (Klinger et al. 1995), and as high as 868 ppmv in tank U-103 (Ligotke et al. 1995). Under the proper conditions, nitrous oxide can serve as an oxidizer to support combustion. However, Cashdollar et al. (1992) found that nitrous oxide had no significant effect on the flammability of hydrogen and air mixtures for hydrogen concentrations less than $20 \mathrm{vol} \%$, and that "small amounts of nitrous oxide (relative to air) do not appear to have much effect on the flammability". Their results suggest the measured nitrous oxide concentration is much too low to have a significant effect on the flammability of the tank U-204 headspace.

\subsection{Carbon Monoxide and Carbon Dioxide}

Carbon monoxide in the tank U-204 headspace was measured to be $<25$ ppmv. In ambient air it typically ranges from 0.05 to $0.15 \mathrm{ppmv}$. Because different analytical methods have been used to measure carbon monoxide in the waste tanks sampled to date, the information on carbon monoxide has varied from tank to tank. However, elevated waste tank headspace carbon monoxide concentrations are common, and are

1 SUMMA is a trademark of Molectrics, Inc., Cleveland, Ohio. 
WHC-SD-WM-ER-513 Rev. 0

thought to be due to the decomposition of organic waste in the tanks. Carbon monoxide has not been measured at very high levels in any of the waste tanks, the highest level measured to date was [26.7 ppmv] in tank C-1032 (Huckaby and Story 1994).

The reported average carbon dioxide concentration in tank U-204 headspace SUMMA ${ }^{\mathrm{TM}}$ samples, $<25$ ppmv, is much lower than it is in ambient air. Carbon dioxide is normally present in the ambient air at a concentration of 350 to $400 \mathrm{ppmv}$, and is typically lower than ambient in the waste tank headspaces. Carbon dioxide introduced by air exchange with the atmosphere is readily absorbed by caustic supernatant and interstitial liquids of the waste tanks, and converted to carbonate in solution. Typical waste tank carbon dioxide concentrations are in the 20 to 200 ppmv range.

\subsection{Nitric Oxide, Nitrogen Dioxide, Water and Tritium}

Nitric oxide and nitrogen dioxide concentrations in the tank U-204 headspace were both determined to be $\leq 0.01$ and $\leq 0.02$ ppmv respectively. These are both acid gases that would have very low equilibrium concentrations above the high pH sludge in tank U-204. The measurable presence of nitric oxide may be due to its formation from oxygen and nitrogen in the radiation field of the headspace. These constituents could potentially serve as oxidizers to support combustion, but at the measured concentrations would have a negligible effect on the flammability of the tank U-204 headspace.

The water vapor concentration of tank U-204 was determined to be about $14.3 \mathrm{mg} / \mathrm{L}$, at the measured tank headspace temperature of $17.8^{\circ} \mathrm{C}$ and pressure of $994.6 \mathrm{mbar}$ (746.1 torr), (WHC 1995b). This corresponds to a water vapor partial pressure of $19.2 \mathrm{mbar}\left(14.4\right.$ torr), to a dew point of $16.9^{\circ} \mathrm{C}$, and to a relative humidity of $94 \%$. This is a relatively high humidity, and is consistent with the waste type being sludge. Precision of the measurement, which was based on 7 samples, was very good, with a relative standard deviation of less than $1 \%$.

Silica gel sorbent traps were used to sample for tritium. It is assumed that tritium produced by the waste combines with hydroxide ions to form tritium-substituted water. Evaporation of the tritium-substituted water would then result in airborne radioactive contamination. Silica gel sorbent traps adsorb virtually all (normal and tritium-substituted) water vapor from the sampled tank air, and are analyzed at the WHC 222S laboratory. Radiochemical analysis of the silica gel trap indicated the total activity of the headspace to be less than 50 pCilL (WHC 1995b).

\subsection{Discussion of Inorganic Gases and Vapors}

Though a trace amount of ammonia was detected and the humidity is high, the tank U-204 samples do,not have appreciable concentrations of any inorganic waste gases or vapors. As is typical for the passively ventllated tanks, carbon dioxide is apparently being absorbed from the air inside tank U-204 by the caustic waste.

The relative standard deviations of the inorganic gas and vapor results given in the last column in Table 31 are good for the water vapor measurement, but very poor for the ammonia measurement. The poor precision of the ammonia measurement is due to the measured value being very near the method

${ }^{2}$ The carbon monoxide measurement in tank C-103 was made by Oregon Graduate Institute of Science and Technology, and placed in brackets to emphasize it'should be considered secondary data. 


\section{WHC-SD-WM-ER-513 Rev. 0}

detection limit. Because the precision reported depends both on sampling parameters (e.g., sample flow rate and flow time for sorbent traps) and analytical parameters (e.g., sample preparation, dilutions, etc.), the small relative standard deviation for the water vapor measurement suggests proper control was maintained both in the field and in the laboratories. 
WHC-SD-WM-ER-513 Rev. 0

\subsection{ORGANIC VAPORS}

Organic vapors in the tank U-204 headspace were sampled using SUMMA ${ }^{\mathrm{TM}}$ canisters and triple sorbent traps (TSTS), which were analyzed by PNL. Gas chromatographs (GCs) equipped with mass spectrometer (MS) detectors were used to separate, identify, and quantitate the analytes. SUMMA ${ }^{\text {TM }}$ canisters were also analyzed according to the Environmental Protection Agency (EPA) task order 12 (TO12) method, for total nonmethane organic carbon (TNMOC), (EPA 1988). The EPA TO-12 method employs a GC equipped with a flame ionization detector.

Sample preparation and analyses were performed at PNL quality assurance impact level 2. Analyses of SUMMA ${ }^{\text {TM }}$ and TST samples were completed 22 and 39 days, respectively, after sample collection, and within the allowed 60-day holding time (Keller 1994). However, no holding time study has been performed to determine the stability of analytes in SUMMA ${ }^{\text {TM }}$ canisters in the chemical matrix of the tank samples. Descriptions of sample device cleaning, sample preparations, and analyses are given by Clauss et al. (1995).

All TSTs were prepared with 3 surrogate compounds added to evaluate sample matrix effects, potential handling, storage, and shipment problems. A statistical treatment of surrogate recoveries has not been performed in part because of insufficient data. Surrogates have been used by PNL only as indicators of gross sample matrix, handling, storage, or shipment problems, and no such problems were indicated in the tank U-204 TST samples.

\subsection{Positively Identified Organic Compounds}

Positive identification of organic analytes using the methods employed by PNL involves matching the GC retention times and MS data from a sample with that obtained when known compounds were analyzed. The concentration of an analyte in the sample is said to be quantitatively measured if the response of the GC/MS has been established at several known concentrations of that analyte (i.e., the GC/MS has been calibrated for that analyte), and the MS response to the analyte in the sample is between the lowest and highest responses to the known concentrations (i.e., the analyte is within the calibration range).

PNL was assigned a list of organic compounds, or target analytes, to positively identify and measure quantitatively. This list included 39 compounds in the EPA task order 14 (TO-14) method, which are primarily halocarbons and common industrial solvents (EPA 1988), plus 14 analytes selected mainly from a toxicology panel's review of vapor data from tank C-103 (Mahlum et al. 1994). In addition, because the TST samples were analyzed several days after the SUMMA ${ }^{\mathrm{TM}}$ samples, the TSTs were analyzed for an additional 9 target analytes that had been added in the interim.

Table 4-1 lists the 3-sample average concentrations of the 3 organic compounds positively identified and quantitated in SUMMA ${ }^{\text {TM }}$ samples. Also given in Table 4-1 is the SUMMA ${ }^{\text {TM }}$ sample result for methane, which was analyzed with the inorganic gases. Propanone (acetone) was above the quantitation limit in only 2 of the SUMMA ${ }^{\mathrm{TM}}$ canister samples. The TO-14 method quantitation limit was 0.005 ppmv.

The TST target analyte results are given in Table 4-2. Like the SUMMA ${ }^{\text {TM }}$ canister analyses, the TST analytical quantitation limit was 0.005 ppmv. No propanone was detected in the TST samples, 4 other halocarbons were detected in TSTs that were not detected in SUMMA ${ }^{\mathrm{TM}}$ canisters.

A comparison of results from these 2 methods is given in Table 4-3. The methods do not agree well in a relative comparison of results for the most abundant constituent (trichlorofluoromethane), but do agree 
that it is the most abundant target analyte, and place its concentration between about 0.57 and $1.1 \mathrm{ppmv}$. The other analytes were not detected in both types of samples, but were at low levels. Agreement between the 2 methods is otherwise reasonably good, given that the measured concentrations of all other 'target analytes are close to the methods' quantitation limits.

\subsection{Tentatively Identified Organic Compounds}

In addition to the target analytes, the ORNL and PNL analytical procedures allow the tentative identification of other organic compounds. Tentative identification of analytes was pérformed by comparing the MS molecular fragmentation patterns with a library of known MS fragmentation patterns. This method allows an organic analyte to be identified (with reasonable certainty) as an alkane, a ketone, an aldehyde, etc., and may also determine its molecular weight. The method usually does not, however, allow the unambiguous identification of structural isomers, and this ambiguity increases with analyte molecular weight. Using this method, many analytes can be tentatively identified with reasonable confidence without having to inject each into the GC/MS to determine their GC retention times or specific MS patterns.

By the nature of the sampling devices, virtually all organic vapors present in the tank headspace are collected by both TST and SUMMA ${ }^{\text {TM }}$ samples. Analyses of the samples are designed to recover, separate, and identify the organic vapors in the samples. TSTs are not good for collecting highly volatile compounds (i.e., molecules more volatile than propane), but are quite good for most others. In contrast, the recovery of very low volatility compounds (e.g., molecules with more than about 15 carbon atoms) and some polar compounds with moderate volatility (e.g., butanal) from SUMMA ${ }^{\mathrm{TM}}$ samples has been problematic.

The lists of tentatively identified compounds, with estimated concentrations, recovered from SUMMATM and TST samples are given in Tables $4-4$ and 4-5, respectively. Estimated concentrations in Tables 4-4 and 4-5 are in $\mathrm{mg} / \mathrm{m}^{3}$, based on dry air at $0^{\circ} \mathrm{C}$ and 1.01 bar. Four compounds were tentatively identified in SUMMA ${ }^{\text {TM }}$ canister samples, and 3 different compounds were tentatively identified in the TST samples. As with the target analytes, the halocarbons are prominent in the SUMMA ${ }^{T M}$ samples. The reporting limit for tentatively identified compounds by both methods is about 0.010 ppmv.

Tributyl phosphate and dibutyl butylphosphonate were detected in 1 of the TST samples, however, there is good reason to doubt the validity of these results. Specifically, relatively high levels of tributyl phosphate have been associated with the number 1 port of the sorbent trap sampling station of the VSS, both in TSTs analyzed by Oak Ridge National Laboratory (Jenkins et al. 1995), and by PNL (Pool et al. 1995). Dibutyl butylphosphonate is a manufacturing contaminant of tributyl phosphate, and is frequently detected when tributyl phosphate is detected, albeit at a lower concentration.

The PNL methods used to tentatively identify and estimate concentrations are described by Clauss et al. (1995), and should be reviewed before these data are used for decision making. Concentrations given in Tables $4-4$ and $4-5$ should be considered estimates.

\subsection{Total Nonmethane Organic Carbon}

The TNMOC in the tank U-204 headspace was determined by analysis of 3 SUMMA'M canister samples using the EPA TO-12 method. The average measured TNMOC concentration was $0.86 \mathrm{mg} / \mathrm{m}^{3}$. For comparison, the ambient air SUMMA ${ }^{T M}$ canister collected upwind of tank U-204 at the start of the sampling 
event was found to have a TNMOC concentration of $0.22 \mathrm{mg} / \mathrm{m}^{3}$. The average TNMOC concentration of the tank air samples is much lower than the sum of quantitated and estimated organic vapors in SUMMA ${ }^{\mathrm{TM}}$ canisters by GC/MS $\left(7.02 \mathrm{mg} / \mathrm{m}^{3}\right)$, and that in TST samples by GC/MS $\left(4.23 \mathrm{mg} / \mathrm{m}^{3}\right)$. The primary reason for these differences is that the flame ionization detector employed in the EPA TO-12 method is insensitive to halocarbons (or any nonflammable constituent), and these represent a majority of the organic material on a mass concentration basis.

\subsection{Discussion of Organic Compounds}

The primary organic compounds identified in tank U-204 were halocarbons. The source of these is unknown, but trichlorofluoromethane has been associated with the urethane foam used to seal concrete pits on the single shell tanks. The plausibility of this explanation for freons in tank U-204 has not been confirmed.

Aside from the halocarbons, tank U-204 is relatively devoid of organic vapors. TSTs are relatively reliable for sampling semivolatile compounds, yet none of the commonly detected semivolatile normal paraffinic hydrocarbons (NPHs), which were target analytes for the TSTs, were detected above the 0.005 ppmv quantitation limit.

Though tributyl phosphate and dibutyl butylphosphonate were detected in 1 TST sample, it is very likely that their presence in that TST is due to contamination of the sampling port of the VSS at which it was collected. The source of contamination is not known, but may have been present in this isolated part of the sampling manifold since the VSS underwent performance testing in 1994. This particular part of the sampling manifold had not been used to collect samples until equipment modifications were made in May 1995. Dibutyl butyiphosphonate is a manufacturing impurity of tributyl phosphate, and is generally present at low concentrations in conjunction with tributyl phosphate.

Though the tributyl phosphate detected in the single TST sample is thought to be due to contamination, there is still a possibility that tributyl phosphate does exist in tank U-204. Informal tests by ORNL indicate that tributyl phosphate and dibutyl butylphosphonate are adsorbed by the glass-fiber high efficiency particulate air filters used in the VSS to protect samples from radiological particles. Consequently, it is assumed that the lack of these constituents in tank air samples does not constitute proof that they are not present. Furthermore, the positive identification of 1 -butanol in 1 of the SUMMA ${ }^{\text {TM }}$ canister samples does suggest there may be small amounts of tributyl phosphate in tank U-204. 1-Butanol is a known hydrolysis product of tributyl phosphate, and is frequently observed in the passively ventilated tanks with NPH and tributyl phosphate.

The tank U-204 headspace has low levels of organic vapors compared to other waste tanks sampled to date. The most abundant constituents (halocarbons) are nonflammable, and none of the other organic constituents, individually or cumulatively, are present at high enough concentrations to pose a flammability hazard. 


\subsection{SUMMARY}

The tank U-204 headspace was sampled in August 1995 for gases and vapors to address flammability and industrial hygiene concerns. Collection and analysis of samples has been reported. It was determined that no headspace constituents exceeded the flammability or industrial hygiene notification limits specified in the current Vapor Sampling and Analysis Plan (Homi 1995b). 


\section{WHC-SD-WM-ER-513 Rev. 0}

\subsection{REFERENCES}

29 CFR 1910.120, 1993, "Hazardous Waste Operations and Emergency Response", Code of Federal Regulations.

Burnum, S. T., 1995, Qualification of Reported WHC Vapor Program Data, (letter 95-CHD-065 to president, Westinghouse Hanford Company, August 18), Department of Energy, Richland Operations Office, Richland, Washington.

Cashdollar, K. L., M. Hertzberg, I. A. Zlochower, C. E. Lucci, G. M. Green, and R. A. Thomas, 1992, Laboratory Flammability Studies of Mixtures of Hydrogen, Nitrous Oxide, and Air, WHC-SD-WMES-219 Rev. 0, Westinghouse Hanford Company, Richland, Washington.

Clauss, T. W. J. C. Evans, B. D. MoVeety, K. H. Pool, K. B. Olsen, J. S. Fruchter, and M. W. Ligotke, 1995, Vapor Space Characterization of Waste Tank 241-U-204: Results from Samples Collected on 8/8/95, PNL-10811 UC-606, Pacific Northwest Laboratory, Richland, Washington.

Dougherty, L. F., 1995, Single Shell Tank Interim Operational Safety Requirements, WHC-SD-WM-OSR005 Rev. 0, Westinghouse Hanford Company, Richland, Washington.

EPA 1988, Compendium of Methods for the Determination of Toxic Organic Compounds in Ambient Air, PB90-127374, U.S. Environmental Protection Agency, Washington, D.C.

Homi, C. S., 1995a, Tank 241-U-204 Tank Characterization Plan, WHC-SD-WM-TP-311, Rev. 0, Westinghouse Hanford Company, Richland, Washington.

Homi, C. S., 1995b, Vapor Sampling and Analysis Plan, WHC-SD-WM-TP-335 Rev. OG, Westinghouse Hanford Company, Richland, Washington.

Huckaby, J. L., 1994, Tank 241-C-103 Headspace Flammability, WHC-EP-0734 Rev. 1, Westinghouse Hanford Company, Richland, Washington.

Huckaby, J. L., H. Babad, and D. R. Bratzel, 1995, Headspace Gas and Vapor Characterization Summary for the 43 Vapor Program Suspect Tanks, WHC-SD-WM-ER-514 Rev. 0, Westinghouse Hanford Company, Richland, Washington.

Huckaby, J. L., and M. S. Story, 1994, Vapor Characterization of Tank 241-C-103, WHC-EP-0780 Rev. 0, Westinghouse Hanford Company, Richland, Washington.

Jenkins, R. A, A. B. Dindal, C. Y. Ma, M. A. Palausky, J. T. Skeen, and C. K. Bayne, 1995, Analysis of Tank 241-A-101 Headspace Components, ORNL-CASD-FR-241A101.95 Rev. 0, Oak Ridge National Laboratory, Oak Ridge, Tennessee.

Keller, K. K., 1994, Quality Assurance Project Plan for Tank Vapor Characterization, WHC-SD-WMQAPP-013 Rev. 2, Westinghouse Hanford Company, Richland, Washington.

Klinger, G. S., T. W. Clauss, M. W. Ligotke, K. H. Pool, R. B. Lucke, B. D. MoVeety, O. P. Bredt, J. S. Young, M. McCulloch, J. S. Fruchter, and S. C. Goheen, 1995, Vapor Space Characterization of Waste Tank 241-TX-105: Results from Samples Collected Through the Vapor Sampling System on 12/20/94, PNL-10594 UC-606, Pacific Northwest Laboratory, Richland, Washington. 


\section{WHC-SD-WM-ER-513 Rev, 0}

Ligotke, M. W., K. H. Pool, T. W. Clauss, B. D. MoVeety, G. S. Klinger, K. B. Olsen, O. P. Bredt, J. S. Fruchter, and S. C. Goheen, 1995b, Vapor Space Characterization of Waste Tank 241-U-103: Results from Samples Collected on 2/15/95, PNL-10813 UC-606, Pacific Northwest Laboratory, Richland, Washington.

Mahlum, D. D., J. Y. Young, and R. E. Weller, 1994, Toxicologic Evaluation of Analytes from Tank 231-C103, PNL-10189, Pacific Northwest Laboratory, Richland, Washington.

McVeety, B. D., T. W. Clauss, M. W. Ligotke, K. H. Pool, R. B. Lucke, G. S. Klinger, J. S. Young, M. McCulloch, J. S. Fruchter, and S. C. Goheen, 1995, Vapor Space Characterization of Waste Tank 241-BY-108: Results from Samples Collected on 10/27/94, PNL-10495 UC-606, Pacific Northwest Laboratory, Richland, Washington.

Meacham, J. E., H. Babad, R. J. Cash, G. T. Dukelow, S. J. Eberlein, D. W. Hamilton, G. D. Johnson, J. W. Osborne, M. A. Payne, D. J. Sherwood, D. A. Turner, and J. L. Huckaby, 1995, Approach for Tank Safety Characterization of Hanford Site Waste, WHC-EP-0843 Rev. 0, UC-2070, Westinghouse Hanford Company, Richland, Washington.

NFPA 1992, Standard on Explosion Prevention Systems, NFPA 69, National Fire Protection Association, Quincy, Massachusetts.

Osborne, J. W., and J. L. Huckaby, 1994, Program Plan for the Resolution of Tank Vapor Issues, WHCEP-0562 Rev. 1, Westinghouse Hanford Company, Richland, Washington.

Osborne, J. W., J. L. Huckaby, T. P. Rudolph, E. R. Hewitt, D. D. Mahlum, J. Y. Young, and C. M. Anderson, 1995, Data Quality Objectives for Generic In-Tank Health and Safety Issue Resolution, WHC-SD-WM-DQO-002 Rev. 1, Westinghouse Hanford Company, Richland, Washington.

Pool, K. H., T. W. Clauss, M. W. Ligotke, B. D. MoVeety, J. C. Evans, K. B. Olsen, J. S. Fruchter, and S. C. Goheen, 1995, Vapor Space Characterization of Waste Tank 241-A-101: Results from Samples Collected on 6/8/95, PNL-10808 UC-606, Pacific Northwest Laboratory, Richland, Washington.

WHC 1995a, Operating Specifications for Watchlist Tanks, OSD-T-151-00030, Rev. B-9, Westinghouse Hanford Company, Richland, Washington.

WHC 1995b, Vapor and Gas Sampling of Single-Shell Tank 241-U-204 Using the Vapor Sampling System, WHC-SD-WM-RPT-155, Westinghouse Hanford Company, Richland, Washington. 


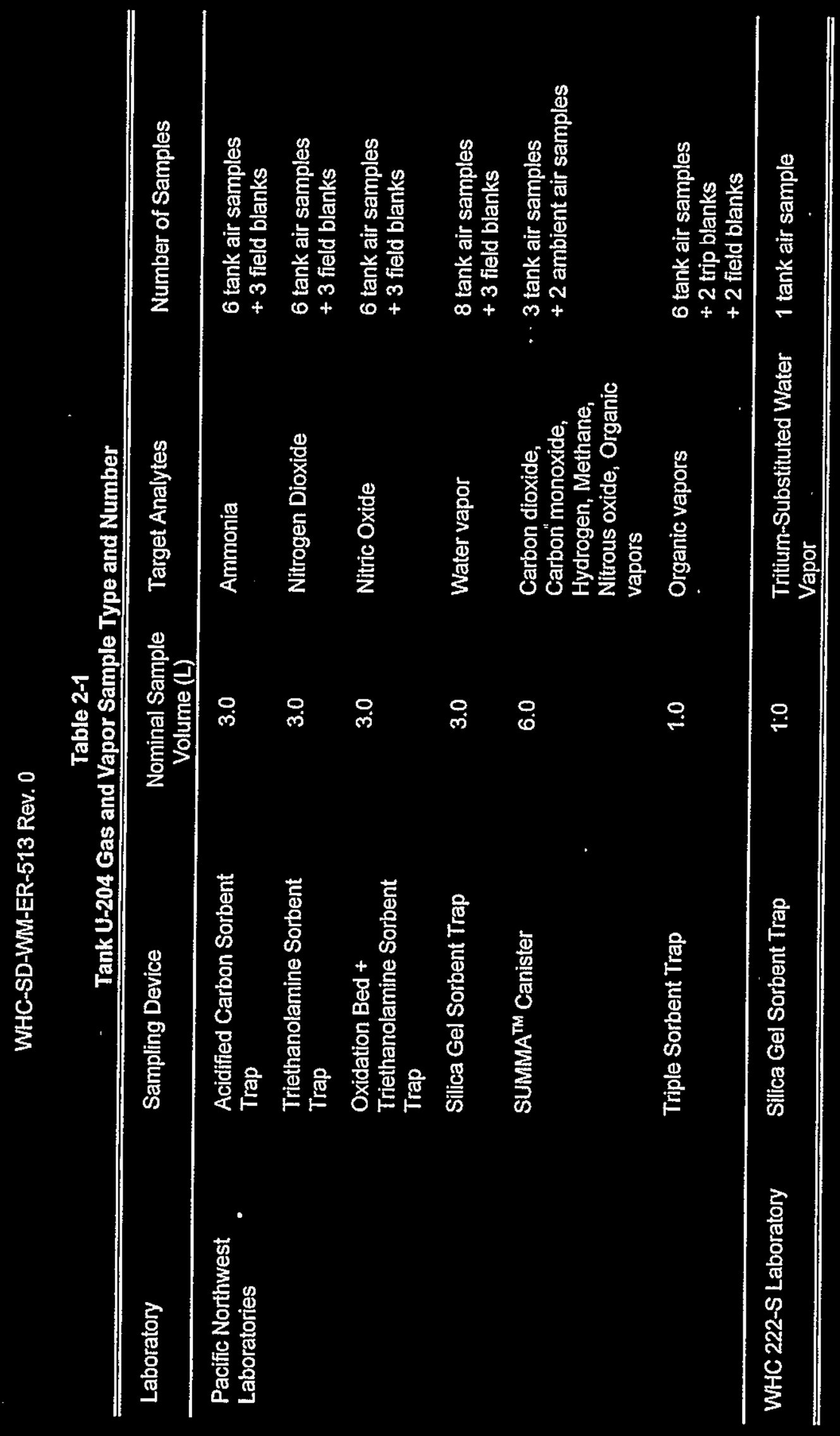


WHC-SD-WM-ER-513 ReV. 0

Table 3-1

Tank U-204 Inorganic Gas and Vapor Concentrations

\begin{tabular}{|c|c|c|c|c|c|c|}
\hline Compound & $\begin{array}{c}\text { CAS }^{1} \\
\text { Number }\end{array}$ & $\begin{array}{l}\text { Sample } \\
\text { Type }\end{array}$ & $\begin{array}{c}\text { Number } \\
\text { of } \\
\text { Samples }\end{array}$ & $\begin{array}{c}\text { Average } \\
\text { (ppmv) }\end{array}$ & $\begin{array}{c}\text { Standard } \\
\text { Deviation } \\
\text { (ppmv) } \\
\end{array}$ & $\begin{array}{c}\mathrm{RSD}^{2} \\
(\%)\end{array}$ \\
\hline Ammonia, $\mathrm{NH}_{3}$ & $7664-41-7$ & Sorbent Trap & 6 & 0.1 & 0.1 & 100 \\
\hline Carbon Dioxide, $\mathrm{CO}_{2}$ & $124-38-9$ & . SUMMA & 3 & $<25$ & - & - \\
\hline Carbon Monoxide, Co & $630-08-0$ & SUMMA ${ }^{\text {TM }}$ & 3 & $<25$ & - & - \\
\hline Hydrogen, $\mathrm{H}_{2}^{\circ}$ & $1333-74-0$ & SUMMA ${ }^{\text {TM }}$ & 3 & $<25$ & - & - \\
\hline Nitric Oxide, NO & $10102-43-9$ & Sorbent Trap & 6 & $\leq 0.01$ & - & - \\
\hline Nitrogen Dioxide, $\mathrm{NO}_{2}$ & $10102-44-0$ & Sorbent Trap & 6 & $\leq 0.02$ & - & - \\
\hline Nitrous Oxide, $\mathrm{N}_{2} \mathrm{O}$ & $10024-97-2$ & SUMMA ${ }^{T M}$ & 3 & $<25$ & - & - \\
\hline Water Vapor, $\mathrm{H}_{2} \mathrm{O}$ & $7732-18-5$ & Sorbent Trap & 7 & $\begin{array}{r}19,300 \\
\quad(14.3 \mathrm{mg} / \mathrm{L}) \\
\end{array}$ & $\begin{array}{l}160 \\
(0.1 \mathrm{mg} / \mathrm{L})\end{array}$ & 0.8 \\
\hline
\end{tabular}

$1 \mathrm{CAS}=$ Chemical Abstracts Service.

2 RSD = relative standard deviation. Burnum (1995) specifies the RSD should be less than $25 \%$. 
WHC-SD-WM-ER-513 Rev. 0

Table 4-1

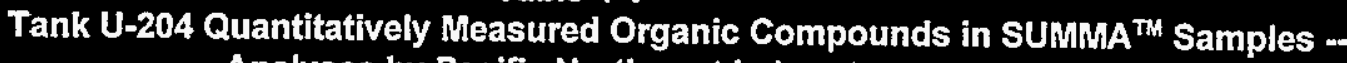
Analyses by Pacific Northwest Laboratory

\begin{tabular}{|c|c|c|c|c|c|}
\hline Cmpd & Compound & $\begin{array}{c}\text { CAS }^{1} \\
\text { Number }\end{array}$ & $\begin{array}{c}\text { Average }^{2} \\
\text { (ppmv) }\end{array}$ & $\begin{array}{c}\text { Standard } \\
\text { Deviation }{ }^{3} \\
\text { (ppmv) }\end{array}$ & $\begin{array}{c}\mathrm{RSD}^{4} \\
(\%)\end{array}$ \\
\hline 1 & Propanone (acetone) $^{5}$ & $67-64-1$ & 0.011 & 0.0019 & 34 \\
\hline 2 & Trichlorofluoromethane & $75-69-4$ & 1.1 & 0.076 & 7 \\
\hline 3 & $\begin{array}{l}\text { Tetrachloromethane (carbon } \\
\text { tetrachloride) }\end{array}$ & $56-23-5$ & 0.0094 & 0.0007 & 7 \\
\hline 4 & Methane & $74-82-8$ & $<25$ & - & - \\
\hline \multicolumn{3}{|c|}{ Sum of positively identified compounds: } & 1.09 & $\mathrm{~g} / \mathrm{m}^{3}$ & \\
\hline
\end{tabular}

$1 \mathrm{CAS}=$ Chemical Abstract Service.

2 Average of 3 samples.

3 When the analyte was detected in only 2 samples, the entry is the average difference (i.e., their difference divided by 2 ).

4 RSD = relative standard deviation. Burnum (1995) specifies the RSD should be less than $25 \%$. When detected in only 2 samples, the entry is the relative percent difference (i.e., their difference divided by their means times $100 \%$ ).

5 Detected in only 2 samples. 
WHC-SD-WM-ER-513 Rev. 0

Table 4-2

Tank U-204 Quantitatively Measured Organic Compounds in TST Samples -Analyses by Pacific Northwest Laboratory

\begin{tabular}{|c|c|c|c|c|c|}
\hline Cmpd & Compound & $\begin{array}{c}\mathrm{CAS}^{1} \\
\text { Number }\end{array}$ & $\begin{array}{c}\text { Average }^{2} \\
\text { (ppmv) }\end{array}$ & $\begin{array}{c}\text { Standard }^{3} \\
\text { Deviation } \\
\text { (ppmv) }\end{array}$ & $\begin{array}{c}\operatorname{RSD}^{4} \\
(\%)\end{array}$ \\
\hline 1 & Dichlorodifluoromethane ${ }^{5}$ & $75-71-8$ & 0.0049 & 0.0017 & 69 \\
\hline 2 & Chloromethane ${ }^{5}$ & $74-87-3$ & 0.0084 & 0.0002 & 5 \\
\hline 3 & Chloroethane $^{6}$ & $75-00-3$ & 0.006 & - & - \\
\hline 4 & Trichlorofluoromethane & $75-69-4$ & 0.573 & 0.023 & 4 \\
\hline 5 & Dichloromethane (methylene chloride) & $75-09-2$ & 0.006 & 0.0016 & 27 \\
\hline 6 & Tetrachloromethane (carbon tetrachloride) & $56-23-5$ & 0.006 & 0.0003 & 5 \\
\hline 7 & 1-Butanol, & $71-36-3$ & 0.011 & - & - \\
\hline
\end{tabular}

$1 \mathrm{CAS}=$ Chemical Abstract Service.

2 Average of $3,1-2$ samples.

3 When the analyte was detected in only 2 samples, the entry is the average difference (i.e., their difference divided by 2).

4 RSD = relative standard deviation. Burnum (1995) specifies the RSD should be less than $25 \%$. When detected in only 2 samples, the entry is the relative percent difference (i.e., their difference divided by their means times $100 \%$ ).

5 Detected in only 2 samples.

6 Detected in only 1 sample.

7 This analyte was not a target analyte for SUMMA ${ }^{\mathrm{TM}}$ canister analyses. 
WHC-SD-WM-ER-513 Rev. 0

Table 4-3

Tank U-204 Comparison of TST and SUMMA ${ }^{\mathrm{TM}}$ Sample Quantitative Results -Analyses by Pacific Northwest Laboratory

\begin{tabular}{lcccc}
\hline Compound & $\begin{array}{c}\text { CAS }^{1} \\
\text { Number }\end{array}$ & $\begin{array}{c}\text { TST } \\
\text { Average } \\
\text { (ppmV) }\end{array}$ & $\begin{array}{c}\text { SUMMATM }^{\text {Average }} \\
\text { (ppmv) }\end{array}$ & $\begin{array}{c}\mathrm{RPD}^{4} \\
(\%)\end{array}$ \\
\hline \hline Propanone (acetone) & $67-64-1$ & $<0.005$ & $0.011^{5}$ & - \\
Dichlorodifluoromethane & $75-71-8$ & $0.0049^{5}$ & $<0.005$ & - \\
Chloromethane & $74-87-3$ & $0.0084^{5}$ & $<0.005$ & - \\
Chloroethane & $75-00-3$ & $0.006^{6}$ & $<0.005$ & - \\
Trichlorofluoromethane & $75-69-4$ & 0.573 & 1.1 & 192 \\
Dichloromethane (methylene chloride) & $75-09-2$ & 0.006 & $<0.005$ & -- \\
Tetrachloromethane (carbon tetrachloride) & $56-23-5$ & 0.006 & 0.0094 & 16 \\
\hline \hline
\end{tabular}

$1 \mathrm{CAS}=$ Chemical Abstract Service.

2 Average of 3 TST, 14L samples.

3 Average of 3 SUMMA ${ }^{\text {TM }}$ samples.

$4 \mathrm{RPD}=$ relative percent difference. Keller (1994) requires the RPD to be less than $20 \%$.

5 This compound detected in oniy 2 samples.

6 This compound detected in only 1 sample. 
WHC-SD-WM-ER-513 Rev. 0

Table 4-4

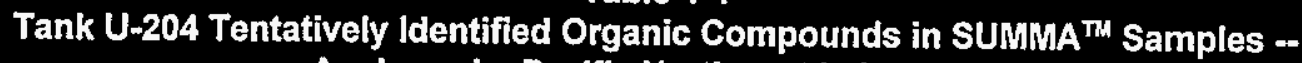
Analyses by Pacific Northwest Laboratory

\begin{tabular}{clcccc}
\hline $\begin{array}{c}\text { Cmpd } \\
\#\end{array}$ & Compound & $\begin{array}{c}\text { CAS } \\
\text { Number }\end{array}$ & $\begin{array}{c}\text { Average } \\
\left(\mathrm{mg}^{2} \mathrm{~m}^{3}\right)\end{array}$ & $\begin{array}{c}\text { Standard } \\
\text { Deviation } \\
\left(\mathrm{mg} / \mathrm{m}^{3}\right)\end{array}$ & $\begin{array}{c}\mathrm{RSD}^{3} \\
(\%)\end{array}$ \\
\hline \hline 1 & Propane & $74-98-6$ & 0.11 & 0.05 & 45 \\
2 & Methane, dichlorofluoro- & $75-43-4$ & 0.10 & 0.01 & 10 \\
3 & Carbon disulfide & $75-15-0$ & 0.17 & 0.02 & 12 \\
4 & Unknown C5 Alkene/Cycloalkane & & 0.16 & - & - \\
\hline \hline Sum of tentatively identified compounds: & & 0.038 & & \\
\hline \hline
\end{tabular}

$1 \mathrm{CAS}=$ Chemical Abstract Service.

2 Based on analyses of 3 samples. Values given are estimates.

3 RSD = relative standard deviation. Burnum (1995) specifies the RSD should be less than $25 \%$.

4 Detected in only 1 sample. 
WHC-SD-WM-ER-513 ReV. 0

Table 4-5

Tank U-204 Tentatively Identified Organic Compounds in TST Samples Analyses by Pacific Northwest Laboratory

\begin{tabular}{|c|c|c|c|c|c|}
\hline$\underset{\#}{C m p d}$ & Compounds & $\begin{array}{c}\text { CAS }^{1} \\
\text { Number }\end{array}$ & $\begin{array}{c}\text { Average }^{2} \\
\left(\mathrm{mg} / \mathrm{m}^{3}\right)\end{array}$ & $\begin{array}{c}\text { Standard } \\
\text { Deviation } \\
\left(\mathrm{mg} / \mathrm{m}^{3}\right)\end{array}$ & $\begin{array}{c}\mathrm{RSD}^{4} \\
(\%)\end{array}$ \\
\hline 1 & Ethane, 1-chloro-1,1-difluoro- ${ }^{5}$ & $75-68-3$ & 0.079 & 0.011 & 28 \\
\hline 2 & Dibutyl butylphosphonate ${ }^{6}$ & $78-46-6$ & 0.067 & - & - \\
\hline 3 & Tributyl Phosphate ${ }^{6}$ & $126-73-8$ & 0.73 & - & - \\
\hline \multicolumn{3}{|c|}{ Sum of Tentatively Identified Compounds: } & 0.876 & & \\
\hline
\end{tabular}

$1 \mathrm{CAS}=$ Chemical Abstract Service.

2 Based on analysis of 3 samples. Values given are estimates.

3 When the analyte was detected in only 2 samples, the entry is the average difference (i.e., their difference divided by 2).

$4 \mathrm{RSD}=$ relative standard deviation. Burnum (1995) specifies the RSD should be less than $25 \%$. When detected in only 2 samples, the entry is the relative percent difference (i.e., their difference divided by their means times $100 \%$ ).

5 Detected in only 2 samples.

6 Detected in only 1 sample. 